В.М. Лехан ${ }^{1}$, Л.В. Крячкова ${ }^{1}$, В.М.Сердюк ${ }^{2}$, Н.В. Пучкова ${ }^{2}$, Е.В.Борвинко ${ }^{1}$, Л.О. Гриценко ${ }^{1}$, М.І. Заярський ${ }^{1}$

\title{
Оцінка важливості проблеми захворювань, що піддаються амбулаторному лікуванню в Україні
}

\author{
${ }^{1}$ Д3 «Дніпропетровська медична академія МО3 України», м. Дніпро, Україна \\ ${ }^{2}$ Департамент охорони здоров'я Дніпропетровської обласної державної адміністрації, м. Дніпро, Україна
}

v.n.lexan@gmail.com,guoz@adm.dp.gov.ua, social.medicine.pg@dma.dp.ua

\author{
В.Н. Лехан ${ }^{1}$, Л.В. Крячкова ${ }^{1}$, В.Н.Сердюк ${ }^{2}$, Н.В. Пучкова ${ }^{2}$, \\ Э.В. Борвинко ${ }^{1}$, Л.А. Гриценко ${ }^{1}$, Н.И. Заярский ${ }^{1}$ \\ Оценка важности проблемы заболеваний, \\ поддающихся амбулаторному лечению в Украине \\ ${ }^{1} Г У$ «Днепропетровская медицинская академия \\ МЗ Украины» \\ ${ }^{2}$ Департамент здравоохранения \\ Днепропетровской облгосадминистрации
}

V.M. Lekhan, L.V. Kryachkova, V.M. Serdyuk, N.V. Puchkova, E.V. Borvinko, L.O. Gritsenko, M.I. Zayarsky

Assessment of the Importance of the problem of ambulatory care sensitive conditions in Ukraine ${ }^{1} \mathrm{SE}$ «Dnepropetrovsk Medical Academy of the Ministry of Health of Ukraine»

${ }^{2}$ Department of Health of the Dnipropetrovsk Regional State Administration

\section{Вступ}

В умовах наявної чи потенційної пандемії (епідемії) коронавірусної інфекції 2019 (COVID-19) виявляються усі існуючі проблеми в організації діяльності систем охорони здоров'я, як у галузі громадського здоров'я, так і в секторах надання амбулаторної та стаціонарної допомоги.

Всесвітня організація охорони здоров'я (ВООЗ) підкреслює, що COVID-19 демонструє, наскільки неміцними $є$ системи охорони здоров'я і відповідно найкращим знаряддям захисту від спалаху будь-якої хвороби є їх зміцнення у напрямі визначення пріоритету зусиль для забезпечення безперервності надання послуг i перерозподілу все більш обмежених ресурсів, 3 тим щоб вони могли приносити максимальну користь населенню [13].

Зростає увага країн до оптимізації діяльності систем охорони здоров'я шляхом зміщення акцентів 3 витратних стаціонарних послуг, ресурси яких потрібні для оперативного реагування на актуальні загрози та лікування пацієнтів у важких станах, на послуги, що без втрати якості обслуговування, можуть ефективно забезпечуватися первинною медико-санітарною допомогою (ПМСД).

В останні роки світовим трендом при розробці політики зміцнення систем охорони здоров'я $\epsilon$ впровадження стратегії зменшення обсягів госпіталізацій та екстреної медичної допомоги через вплив на захворювання, що піддаються амбулаторному лікуванню або амбулаторно-чутливі стани (ЗПАЛ; англ. Ambulatory care sensitive conditions - ACSC) [9].

Концепція ЗПАЛ була введена у медичну практику наприкінці 1980-х років Дж. Біллінгсом з Нью-Йоркського університету у якості підходу до уникнення госпіталізацій незастрахованих пацієнтів шляхом своєчасного та ефективного надання амбулаторної допомоги [11]. Перше застосування ЗПАЛ у європейському контексті зробили Caminal J. et al. у 2004 році, припускаючи, що ці захворювання можуть бути показником ефективності ПМСД для вирішення проблем зі здоров'ям. Автори проаналізували 113 захворювань згідно кодів Міжнародної статистичної класифікації хвороб та споріднених проблем охорони здоров'я (MКХ) 9 перегляду та зупинилися на переліку з 19-ти ЗПАЛ [12]. 3 того часу різні країни (Німеччина, Португалія, Іспанія, Великобританія, Ірландія, Латвія, Молдова, Казахстан та інші) та різні міжнародні організації, включаючи ВОО3, займалися проблемою вивчення захворювань, що піддаються амбулаторному лікуванню: уточнювалися дефініції та визначення, адаптувався до національних умов і корегувався список ЗПАЛ [4-9].

На теперішній час ЗПАЛ визначаються як стани здоров'я, при яких можна уникнути госпіталізацій шляхом своєчасного та ефективного надання медичної допомоги в амбулаторних умовах. При цьому амбулаторна допомога включає медичні послуги загального (первинного) та спеціалізованого (вторинного) рівня [9].

Purdy S. et al. у 2009 р. на прикладі Великобританії визначили 36 потенційних ЗПАЛ [16]. Bardsley M. et al. на підставі результатів досліджень попередників та використовуючи власний досвід, визначили 27 клінічних станів ЗПАЛ, які були розділені на три групи: гострі хвороби або стани, коли раннє втручання може запобігти серйозному прогресуванню захворювання; хронічні хвороби або стани, коли ефективне управління випадками попереджує ускладнення; та стани, яким можна запобігти шляхом вакцинації - коли імунізація й інші втручання зводять до мінімуму виникнення певних захворювань [10]. 
Найчастіше у європейській практиці використовується даний підхід. Саме він застосовувався у масштабному проекті ВОО3 2016 р., коли проводилися паралельні оцінки ЗПАЛ у Німеччині, Казахстані, Латвії, Португалії та Республіці Молдова. Маркерні патології обиралися країнами із загального списку 27 ЗПАЛ в залежності від національних умов та обмежень статистичного обліку [4-9].

Згідно керівництва 3 оцінки ЗПАЛ у Європі, необхідно зробити низку ключових кроків для проведення оцінки щодо захворювань, які піддаються амбулаторному лікуванню в країні: визначення та налаштування - огляд існуючої наукової та іншої інформації, що має відношення до ЗПАЛ; відбір даних - отримання матеріалів щодо рівня госпіталізації в країні зі ЗПАЛ; встановлення пріоритетів щодо ЗПАЛ - визначення за даними анкетування вичерпного переліку амбулаторно-чутливих станів (перелік з 8-10 захворювань) та найбільш пріоритетних ЗПАЛ (2-4 захворювання: щонайменше одне гостре, одне хронічне та одне вакцино-кероване захворювання) репрезентативних маркерів для подальшої оцінки частки госпіталізацій при ЗПАЛ, як індикаторів ефективності надання ПМСД; консультації із зацікавленими сторонами, такими як представники постачальників медичних послуг, адміністраторів, політиків, дослідників тощо; формулювання рекомендацій щодо політики в охороні здоров'я, і представлення результатів оцінки [9].

За даними проведених Європейських досліджень, обсяг госпіталізацій, яких можна уникнути за рахунок ефективного медичного обслуговування на первинному рівні, коливається від 40\% до 80\% для найбільш значущих ЗПАЛ (діабету, артеріальної гіпертензії (АГ), захворювань нирок та інфекції сечовивідних шляхів і серцевої недостатності) [4-9].

Останніми роками проводиться оцінка різних аспектів надання ЗПАЛ, включаючи якість, ефективність, безпеку та доступність первинних послуг і медичної допомоги в цілому, координацію між постачальниками медичних послуг тощо [14,17].

Незважаючи на зацікавленість та активність у вимірюванні i звітності щодо ЗПАЛ, зберігаються відмінності у визначеннях та підходах до їх вимірювання у різних країнах. Попри інтерес до даного питання у Свропейському регіоні ВООЗ та зацікавленості України у проведенні досліджень щодо зменшення обсягів необгрунтованих госпіталізацій [3,18], нами не було виявлено проведених досліджень щодо ЗПАЛ у нашій країні, що i обумовило актуальність проведеного дослідження.

Мета дослідження - виявлення найбільш актуальних на теперішній час захворювань, що піддаються амбулаторному лікуванню для дорослого населення (старше 18-ти років) України (вичерпний перелік 3 810 захворювань) та визначення найбільш пріоритетних маркерних ЗПАЛ, як індикаторів ефективності надання первинної допомоги (2-4 захворювання).

\section{Матеріали та методи}

Дослідження проведено відповідно до методологічної основи багатоцентрового дослідження ЗПАЛ в Європейському регіоні [9] 3 певними модифікаціями та адаптацією до національних умов i нагальних потреб, та 3 урахуванням ресурсних можливостей щодо проведення дослідження подібного масштабу без відповідної підтримки з боку національних та міжнародних організацій.

Робота проводилася у декілька етапів: 1) визначення за даними літературних джерел попереднього списку ЗПАЛ; 2) аналіз рівня госпіталізації дорослого населення України за переліком попередньо визначених ЗПАЛ; 3) визначення важливості захворювань, що піддаються амбулаторному лікуванню у дорослого населення в Україні (дана публікація присвячена саме цій частині дослідження та висвітлює й попередні етапи) та 4) подальша оцінка обсягів запобіжних госпіталізацій за повним переліком ЗПАЛ, включаючи й визначені пріоритетні патології.

Попередній список ЗПАЛ (1-й етап), як і в інших аналогічних дослідженнях, сформовано на основі напрацювань Bardsley M. et al. [10], в якій були узагальнені матеріали ключових міжнародних досліджень щодо переліку захворювань, визначених як найбільш важливі амбулаторно-чутливі стани.

На 2-му етапі проведено кроссекційне дослідження госпіталізації дорослого населення в Україні за 2017 рік по кожному 3 визначених на першому етапі ЗПАЛ. Для кожного ЗПАЛ розраховувалися: поширеність захворювання в абсолютних і відносних (на 100 тис. загального населення) показниках, абсолютне число госпіталізованих, рівень госпіталізації на 100 тис. загального населення, рівень госпіталізації від ЗПАЛ (\% госпіталізованих від зареєстрованих хворих 3 даною патологією) та їх питома вага від загального числа госпіталізованих. Для аналізу використано статистичні дані Центру медичної статистики MO3 України (http://medstat.gov.ua/ukr/statdan.html), дані центру громадського здоров'я про інфекційну захворюваність населення України (https://phc.org.ua/kontrolzakhvoryuvan/inshi-infekciyni-zakhvoryuvannya/monitoringi-ocinka/infekciyna-zakhvoryuvanist-naselennya-ukraini),

реєстр пацієнтів 3 туберкульозом Центру громадського здоров'я (https://phc.org.ua/kontrol-zakhvoryuvan/ tuberkuloz/robota-z-reestrom-pacientiv-z-tb) та дані експертних оцінок щодо рівнів госпіталізації від окремих ЗПАЛ статистична інформація за якими була відсутня або недостатня. У якості експертів виступали по 3 висококваліфікованих фахівця відповідної спеціалізації, погодженість думок яких оцінювалася за допомогою коефіцієнту конкордації (W) та думка вважалася узгодженою при наближенні показника погодженості думки до одиниці - $\mathrm{W}>0,70$ ( $\mathrm{p}<0,05)$.

Матеріали для третього та четвертого етапів були отримані шляхом анкетування. Для цього використовувалася модифікована версія інструменту для самооцінки (стандартизованої анкети), запропонованого 
у керівництві по оцінці ЗПАЛ та апробованого в різних країнах Свропи, включно з російськомовним варіантом у Казахстані [4-9].

У якості ключових інформаторів виступали 104 стейкхолдери (зацікавлені сторони), анкети поширювалися через асоціацію сімейних лікарів Дніпропетровської області.

Статистичний аналіз проводився з використанням стандартних методів описової (параметричної i непараметричної) та аналітичної статистики за допомогою програмних продуктів STATISTICA 6.1 (StatSoftInc., серійний № AGAR909E415822FA) та MedCalc Statistical Software trial version 19.2.0 (MedCalc Software bvba, Ostend, Belgium; https://www.medcalc.org; 2020). Визначалися та описувалися центральні тенденції кількісних величини в залежності від типу розподілу даних. Для відносних величин розраховувалися 95,0\% довірчі інтервали (95\%ДI) за відкоригованим методом Вальда. Оцінку статистичної значущості відмінностей кількісних показників проводили за непараметричним дисперсійним аналізом КраскелаУолліса (KW-H) 3 апостеріорними порівняннями за критерієм Дана; відносних показників - за критерієм Хі-квадрат Пірсона $\left(\chi^{2}\right)$.

У якості статистики узгодженості думок та оцінок використовувалися статистика Хі-квадрат, коефіцієнт конкордації (W) і зважену квадратичну каппу Коена (к) із 95\% ДІ, значення якої $<0,20$ вказувало на погану силу узгодженості, 0,21-0,40 - на посередню, 0,41-0,60 на помірну, 0,61-0,80 - на добру, більше за 0,81 - на відмінну [3].

Критичне значення рівня статистичної значущості приймалося для всіх видів аналізу та статистичних тестів на рівні $\mathrm{p}<0,05(5 \%)$

\section{Результати дослідження та їх обговорення}

В Україні протягом 2017 року серед дорослих було зареєстровано 59379593 випадків захворювань і 6601495 хворих, виписаних зі стаціонару. Рівень госпіталізації в Україні за останні 5 років (2014-2018 рр.) залишається практично незмінним і складає 193,8-189,3 на 100 тис. населення. Щодо госпіталізації при амбулаторночутливих станах (табл. 1), то визначається, що найбільший рівень госпіталізації на 100 тисяч загального населення спостерігається переважно при найрозповсюджених захворюваннях - стенокардії (770,6 на 100 тис. нас.), гіпертонічній хворобі (486,2 на 100 тис. нас.), цукровому діабеті (432,6 на 100 тис. нас.), пневмоніях (342,9 на 100 тис. нас.), хронічних обструктивних захворюваннях легень - ХОЗЛ (245,6 на 100 тис. нас.).

Загальний рівень госпіталізації при амбулаторночутливих станах (у \% від числа хворих із ЗПАЛ) за проведеними розрахунками складає $8,1 \%$. При ранжуванні ЗПАЛ з найвищим рівнем госпіталізації визначається що на першому місці знаходяться пневмонії (89,3\%), далі у порядку убування туберкульоз органів дихання (73,8\%), проривна виразка шлунку та 12-палої кишки і шлунковокишкова кровотеча $(69,0 \%)$, вакцино-контрольовані захворювання $(26,6 \%)$, бронхіальна астма $(25,7 \%)$, епілепсія $(21,0 \%)$, сальпінгіт і оофорит $(18,9 \%)$, інфекції шкіри та підшкірної клітковини $(15,0 \%)$, цукровий діабет $(11,9 \%)$, стенокардія $(10,3 \%)$.

Рівень госпіталізації перевищує 50\% при трьох захворюваннях (пневмонії, туберкульозі органів дихання, проривній виразці шлунку та 12-палої кишки і шлунковокишковій кровотечі); при трьох захворюваннях він перевищує 20\% (вакцино-контрольованих захворюваннях, бронхіальній астмі та епілепсії). Отже отриманий перелік 3 шести нозологій можна вважати первинним (сирим) результатом щодо найбільш значущих ЗПАЛ.

Таблиця 1. Рівні госпіталізації дорослих хворих (старше 18 років) з амбулаторночутливими станами в Україні

\begin{tabular}{|c|c|c|c|c|c|c|c|}
\hline \multirow[b]{2}{*}{$\begin{array}{c}\text { ЗПАЛ } \\
\text { (Амбулаторно } \\
\text { чутливі стани) }\end{array}$} & \multirow[b]{2}{*}{$\begin{array}{c}\text { Код } \\
\text { за МКХ } 10\end{array}$} & \multicolumn{2}{|c|}{ Заресстровано хворих } & \multicolumn{4}{|c|}{ Госпіталізовано паціснтів } \\
\hline & & абс. & $\begin{array}{c}\text { на } \\
100 \text { тис. } \\
\text { нас. }\end{array}$ & абс. & $\begin{array}{c}\text { на } \\
100 \text { тис. } \\
\text { нас. }\end{array}$ & 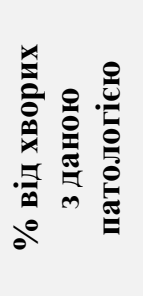 & 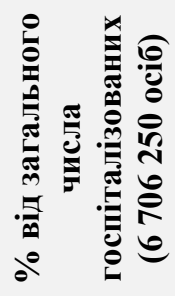 \\
\hline $\begin{array}{l}\text { Вакцино- } \\
\text { контрольовані } \\
\text { інфекційні } \\
\text { захворювання**, } \\
\text { в т.ч. }\end{array}$ & $\begin{array}{c}\text { A15-16, A19, } \\
\text { A35-37, A80, B05, } \\
\text { B06, B16.1, B16.9, } \\
\text { B18.0, B18.1, B26, } \\
\text { G00.0, J10-11, M014 }\end{array}$ & 111734 & 263,4 & 29709 & 85,4 & 26,6 & 0,44 \\
\hline $\begin{array}{l}\text { туберкульоз } \\
\text { органів дихання }\end{array}$ & A15-16, A19 & 32492 & 76,6 & 23979 & 68,9 & 73,8 & 0,36 \\
\hline грип & J10-11 & 15895 & 37,6 & 1590 & 4,6 & 10 & 0,024 \\
\hline $\begin{array}{l}\text { Залізодефіцитна } \\
\text { анемія }\end{array}$ & D50 & 346936 & 997,0 & 10408 & $29,9 *$ & 3 & 0,16 \\
\hline
\end{tabular}




\begin{tabular}{|c|c|c|c|c|c|c|c|}
\hline Цукровий діабет & E10-14 & 1261391 & 3624,8 & 150554 & 432,6 & 11,9 & 2,24 \\
\hline Епілепсія & G40-41 & 28899 & 83,0 & 6069 & $17,4^{*}$ & 21 & 0,09 \\
\hline $\begin{array}{l}\text { Гіпертонічна } \\
\text { хвороба }\end{array}$ & I10-13 & 3704649 & 10645,8 & 169198 & 486,2 & 4,6 & 2,52 \\
\hline Стенокардія & $\mathrm{I} 20$ & 2606040 & 7488,8 & 268164 & 770,6 & 10,3 & 4,00 \\
\hline $\begin{array}{l}\text { Хронічна } \\
\text { серцева } \\
\text { недостатність }\end{array}$ & $\mathrm{I} 50$ & 2000000 & 5813,5 & $\begin{array}{l}20 \text { тис. - } \\
30 \text { тис. }\end{array}$ & $71,8^{*}$ & $1-1,5$ & $0,3-0,45$ \\
\hline Пневмонії & J12-16, J18 & 133621 & 384,0 & 119322 & 342,9 & 89,3 & 1,78 \\
\hline $\begin{array}{l}\text { Хронічні } \\
\text { обструктивні } \\
\text { захворювання } \\
\text { легень }\end{array}$ & $\mathrm{J} 40-42, \mathrm{~J} 44$ & 1235662 & 2554,4 & 85450 & 245,6 & 6,9 & 1,28 \\
\hline $\begin{array}{l}\text { Бронхіальна } \\
\text { астма }\end{array}$ & $\mathrm{J} 45-46$ & 175447 & 504,2 & 45100 & 129,6 & 25,7 & 0,67 \\
\hline $\begin{array}{l}\text { Виразка шлунку } \\
\text { та } 12 \text {-палої } \\
\text { кишки }\end{array}$ & K25-27 & 827746 & 2378,6 & 56119 & 161,3 & 6,8 & 0,84 \\
\hline 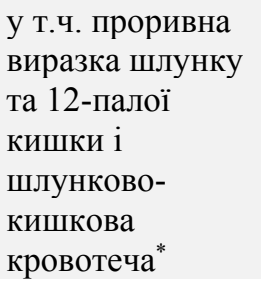 & $\begin{array}{l}\text { K25.1,2,5,6 } \\
\text { K26.1,2,5,6 }\end{array}$ & $35013 *$ & 100,6 & 6145 & $17,6^{*}$ & 69 & 0,09 \\
\hline $\begin{array}{l}\text { Інфекції шкіри } \\
\text { та підшкірної } \\
\text { клітковини }\end{array}$ & L00-08 & 329714 & 947,5 & 49457 & $142,1^{*}$ & 15 & 0,74 \\
\hline Інфекції нирок & N10-12 & 588769 & 1691,9 & 52782 & 151,7 & 9 & 0,79 \\
\hline $\begin{array}{l}\text { Сальпінгіт, } \\
\text { оофорит }\end{array}$ & N70 & 185115 & $\begin{array}{c}970,4 \\
\text { (жін. нас.) }\end{array}$ & 35 тис. $*$ & $100,6^{*}$ & $18,9 *$ & 0,52 \\
\hline Всього за ЗПАЛ & & 13535723 & & 1102332 & & 8,1 & \\
\hline
\end{tabular}

Примітки: Джерела інформації - Центр медичної статистики Міністерства охорони здоров’я України. Статистичні дані (http://medstat.gov.ua/ukr/statdan.html).

* - експертні дані.

** - рівні госпіталізації вакцино-контрольованих захворювань (правець, дифтерія, кашлюк, гострий поліомієліт, кір, краснуха, гострий гепатит В, хронічний гепатит В, епідемічний паротит, гемофільна інфекція, бактеріальний менінгіт) згідно рекомендацій оцінювалися в цілому без розбивки на окремі нозології, оскільки важливою проблемою зі здоров'ям вважається частота госпіталізацій не менше 10 на 100 тис. нас. (у випадку зазначених захворювань вона суттєво нижча).

При співставленні списків ЗПАЛ за частотою госпіталізації на 100 тис. загального населення та рівнем госпіталізації ЗПАЛ (\% від хворих з даною патологією) виявляється погана, статистично незначуща узгодженість ( $=0,027: 95 \%$ ДІ -0,120 - 0,067), що цілком логічно, оскільки розповсюджені амбулаторно-чутливі стани можуть мати низький рівень госпіталізації, тоді як ЗПАЛ, що нечасто зустрічаються можуть мати велику частоту скерованих до стаціонару. У різних країнах Свропи при визначенні доказової бази для аналізу проблеми ЗПАЛ використовувалися різні підходи: у Португалії та Німеччині - аналіз абсолютної кількості госпіталізованих 3 амбулаторно-чутливими станами [4,7]; у Казахстані, Латвії передусім опиралися на рівень госпіталізації ЗПАЛ
[5,6]; у Молдові - на частку ЗПАЛ від загального числа госпіталізованих [8].

Це спонукало нас вибрати найбільш наукометричний підхід - використати для аналізу переважно інтенсивні показники та при опрацюванні статистично-експертних даних провести ранжування ЗПАЛ за рівнем госпіталізації дорослих хворих в Україні після використання коригувальних коефіцієнтів, визначених за показниками частоти госпіталізації в зв'язку з захворювання на 100 тис. населення (ранговим місцем ЗПАЛ у загальному переліку).

Після проведення корегування, список десяти пріоритетних ЗПАЛ в Україні виглядає наступним чином: на перших місцях пневмонія, стенокардія, туберкульоз органів дихання, діабет, гіпертонічна хвороба, вакцино- 
контрольовані захворювання, бронхіальна астма, проривна виразка шлунку та 12-палої кишки і шлунковокишкова кровотеча, інфекції шкіри та підшкірної клітковини, ХОЗЛ; далі у порядку убування: сальпінгіт і оофорит, хронічна виразка шлунку та 12-палої кишки, інфекції нирок, епілепсія, грип, хронічна/застійна серцева недостатність, залізодефіцитна анемія. Але даний перелік ще не $\epsilon$ остаточним, оскільки не враховує рівень значущості ЗПАЛ для України. Саме цей аспект визначався під час опитування ключових інформаторів.

У дослідженні щодо захворювань, які піддаються амбулаторному лікуванню прийняло участь 104 ключових респондентів - експертів в галузі охорони здоров'я та медичних працівників, які $\epsilon$ знавцями 3 організації надання медичної допомоги в Україні, в тому числі і лікарів загальної практики / сімейних лікарів (ЛЗП/СЛ), та здатними відповідати на запитання щодо ЗПАЛ на підставі власного й узагальненого досвіду. Для перевірки надійності отриманих даних їх порівняльний аналіз проводився у розрізі 4-х виділених груп (табл. 2), серед яких відокремлювалася група експертів - більш досвідчених та обізнаних з даного питання фахівців.

У якості експертів виступали 6 фахівців 3 організації охорони здоров'я (OO3), зі стажем роботи 22,5 $(20,0 ; 25,0)$ років - Me $(25 \% ; 75 \%)$, 3 вищою категорією по організації охорони здоров'я, сфера діяльності яких відноситься, як до практичної охорони здоров'я, так і до науково-аналітичної роботи. Розрахунок необхідної кількості експертів, рівня їх обізнаності, аргументованості та компетентності проводилися за стандартною методикою [1] і був вищим достатнього для виконання даної функції рівня (більше 0,8 балів).

Таблиця 2. Загальна характеристика ключових інформаторів, залучених у дослідження щодо амбулаторно чутливих захворювань в Україні

\begin{tabular}{|c|c|c|c|c|c|c|}
\hline Показник & Загалом & ЛЗП/СЛ & $\begin{array}{c}\text { Вузькі } \\
\text { спеціалісти }\end{array}$ & $\begin{array}{c}\text { Фахівці } \\
3003\end{array}$ & Експерти & $\begin{array}{c}\text { р між } \\
\text { групами }\end{array}$ \\
\hline Загальна кількість, n (\%) & $104(100 \%)$ & $71(68,3 \%)$ & $22(21,2 \%)$ & $5(4,8 \%)$ & $6(5,8 \%)$ & - \\
\hline \multicolumn{7}{|l|}{ Місце проживання, n (\%) } \\
\hline місто & $54(51,9)$ & $28(39,4)$ & $17(77,3)$ & $3(60,0)$ & $6(100,0)$ & \multirow{2}{*}{0,001} \\
\hline село & $50(48,1)$ & $43(60,6)$ & $5(22,7)$ & $2(40,0)$ & $0(0)$ & \\
\hline $\begin{array}{l}\text { Перша та вища категорії, } \\
\text { n (\%) }\end{array}$ & $84(80,8)$ & $58(81,7)$ & $17(77,3)$ & $3(60,0)$ & $6(100,0)$ & 0,166 \\
\hline $\begin{array}{l}\text { Стаж роботи } \\
\operatorname{Me}(25 \% ; 75 \%)\end{array}$ & $\begin{array}{c}9,0 \\
(6,0 ; 25,0)\end{array}$ & $\begin{array}{c}9,0 \\
(5,0 ; 19,0)\end{array}$ & $\begin{array}{c}11,0 \\
(8,0 ; 30,0)\end{array}$ & $\begin{array}{c}8,0 \\
(7,0 ; 17,0)\end{array}$ & $\begin{array}{c}22,5 \\
(20,0 ; 25,0)\end{array}$ & $0,067^{*}$ \\
\hline
\end{tabular}

Примітки: $\mathrm{p}$ - розбіжності між групами за критерієм $\chi^{2}$ Пірсона; $\mathrm{p}^{*}$ - розбіжності між групами за непараметричним дисперсійним аналізом Краскела-Уолліса (KW-H).

Розбіжностей між виділеними групами ключових респондентів за стажем та рівнем кваліфікації (категорією) не спостерігалося ( $>0,05)$, однак були наявні статистично значущі розбіжності за місцем їх проживання і роботи $(\mathrm{p}=0,001)$, що враховувалося у подальшому аналізі результатів.

Ключові респонденти були ознайомлені з базовою інформацією про ЗПАЛ в Україні (статистичні дані, доповнені експертно, що наведені у таблиці 1).

Їм було запропоновано доповнити цей список додатковими ЗПАЛ, значущими для України. Лише троє ЛЗП/СЛ $(2,9 \%$ із загальної кількості респондентів) зазначили, що список може бути розширений шляхом додавання до групи вакцино-контрольованих захворювань вітряної віспи та пневмококової інфекції.

Аналіз значущості амбулаторно чутливих захворювань проводився у розрізі трьох підмножин ЗПАЛ та розподілу ключових інформаторів за групами аналізу (табл. 3).

Серед гострих захворювань найвищі пріоритети отримали пневмонія і проривна або кровоточива виразка шлунку та 12-палої кишки. За даними станами, на відміну від запальних захворювань малого таза, розбіжностей у думках груп опитаних не було виявлено (p>0,05). Щодо інфекції нирок й інфекцій шкіри та підшкірної клітковини, то жоден член експертної групи (і майже всі фахівці з ОО3) не відзначив їх як значущі для України.

Щодо хронічних захворювань, то одностайність думок спостерігається щодо значущості таких амбулаторно-чутливих станів, як діабет, артеріальна гіпертензія, стенокардія, ХОЗЛ, бронхіальна астма ( $>0,05)$. Визначено розбіжності у думках опитаних щодо значущості таких ЗПАЛ, як епілепсія та ХСН ( $<<0,05)$, які не вважалися достатньо важливими експертами та фахівцями з ООЗ.

Не визначається одностайності думок респондентів $(\mathrm{p}<0,05)$ і щодо таких захворювань, яких можна запобігти за допомогою імунізації, як туберкульоз органів дихання, який вважають більш значущим ЗПАЛ експерти та сімейні лікарі порівняно 3 іншими групами ключових інформаторів; грип, який вважають більш значущим станом ЛЗП / СЛ та гемофільна інфекція, важливість якої вбачають переважно експерти. У загальному рейтингу значущих вакцино-контрольованих ЗПАЛ домінують дифтерія, туберкульоз органів дихання, кір та правець, щодо яких не визначено розбіжностей у думках ключових респондентів $(\mathrm{p}>0,05)$. 
Таблиця 3. ЗПАЛ в Україні, які потребують особливої уваги на думку ключових інформаторів (частка респондентів що визначили захворювання як найбільш важливе, n (\%))

\begin{tabular}{|c|c|c|c|c|c|c|}
\hline ЗПАЛ & $\begin{array}{c}\text { Загалом } \\
\mathbf{n}=104\end{array}$ & $\begin{array}{c}\text { ЛЗП/СЛ } \\
\mathrm{n}=71\end{array}$ & $\begin{array}{c}\text { Вузькі } \\
\text { спеціалісти } \\
\mathbf{n}=22\end{array}$ & $\begin{array}{c}\text { Фахівці } \\
3 \text { OO3 } \\
\mathbf{n}=5\end{array}$ & $\begin{array}{l}\text { Експерти } \\
\mathbf{n}=6\end{array}$ & $\begin{array}{l}\text { р між } \\
\text { групами }\end{array}$ \\
\hline \multicolumn{7}{|c|}{ Гострі / загострення захворювання } \\
\hline Пневмонія & $92(88,5)$ & $63(88,7)$ & $19(86,4)$ & $4(80,0)$ & $6(100,0)$ & 0,745 \\
\hline $\begin{array}{l}\text { Проривна або кровоточива } \\
\text { виразка шлунку та } \\
12 \text {-палої кишки }\end{array}$ & $78(75,0)$ & $50(70,4)$ & $19(86,4)$ & $3(60,0)$ & $6(100,0)$ & 0,179 \\
\hline Інфекції нирок & $73(70,2)$ & $51(71,8)$ & $16(72,7)$ & $3(60,0)$ & $3(50,0)$ & 0,665 \\
\hline $\begin{array}{l}\text { Запальні захворювання } \\
\text { малого таза (сальпінгіт, } \\
\text { оофорит) }\end{array}$ & $55(52,9)$ & $41(57,8)$ & $13(59,1)$ & $1(20,0)$ & $0(0)$ & 0,019 \\
\hline $\begin{array}{l}\text { Інфекції шкіри та } \\
\text { підшкірної клітковини }\end{array}$ & $45(43,3)$ & $34(47,9)$ & $10(45,5)$ & $1(20,0)$ & $0(0)$ & 0,096 \\
\hline \multicolumn{7}{|c|}{ Хронічні захворювання } \\
\hline Залізодефіцитна анемія & $77(71,1)$ & $53(74,7)$ & $15(68,2)$ & $3(60,0)$ & $3(50,0)$ & 0,388 \\
\hline Діабет & $99(95,2)$ & $69(97,2)$ & $20(90,9)$ & $4(80,0)$ & $6(100,0)$ & 0,229 \\
\hline Епілепсія & $59(56,7)$ & $45(63,4)$ & $11(50)$ & $3(60,0)$ & $0(0)$ & 0,023 \\
\hline Гіпертонічна хвороба/АГ & $91(87,5)$ & $61(85,9)$ & $20(90,9)$ & $4(80,0)$ & $6(100,0)$ & 0,680 \\
\hline Стенокардія & $88(84,6)$ & $60(84,5)$ & $19(86,4)$ & $3(60,0)$ & $6(100,0)$ & 0,325 \\
\hline $\begin{array}{l}\text { Хронічна/застійна серцева } \\
\text { недостатність (ХСН) }\end{array}$ & $60(57,8)$ & $60(84,5)$ & $19(86,4)$ & $4(80,0)$ & $3(50,0)$ & 0,767 \\
\hline ХОЗЛ & $83(79,8)$ & $57(80,3)$ & $18(81,8)$ & $2(40,0)$ & $6(100,0)$ & 0,090 \\
\hline Бронхіальна астма & $83(79,8)$ & $61(85,9)$ & $17(77,3)$ & $2(40,0)$ & $6(100,0)$ & 0,019 \\
\hline $\begin{array}{l}\text { Виразка шлунку та } \\
12 \text {-палої кишки }\end{array}$ & $77(74,0)$ & $52(73,2)$ & $15(68,2)$ & $4(80,0)$ & $6(100,0)$ & 0,455 \\
\hline
\end{tabular}

Захворювання, яким можна запобігти за допомогою імунізації

\begin{tabular}{|l|l|l|l|l|l|l|}
\hline $\begin{array}{l}\text { Туберкульоз органів } \\
\text { дихання }\end{array}$ & $90(86,5)$ & $68(95,8)$ & $14(63,6)$ & $2(40,0)$ & $6(100,0)$ & $<0,001$ \\
\hline Грип & $79(76,0)$ & $59(83,1)$ & $15(68,2)$ & $2(40,0)$ & $3(50,0)$ & 0,037 \\
\hline Правець & $85(81,7)$ & $59(83,1)$ & $17(77,3)$ & $3(60,0)$ & $6(100,0)$ & 0,347 \\
\hline Дифтерія & $91(87,5)$ & $64(90,1)$ & $17(77,3)$ & $4(80,0)$ & $6(100,0)$ & 0,299 \\
\hline Кашлюк & $83(79,8)$ & $62(87,3)$ & $15(68,2)$ & $3(60,0)$ & $3(50,0)$ & 0,031 \\
\hline Гострий поліомієліт & $82(78,9)$ & $58(81,7)$ & $14(63,6)$ & $4(80,0)$ & $6(100,0)$ & 0,171 \\
\hline Кір & $90(86,5)$ & $64(90,1)$ & $17(77,3)$ & $3(60,0)$ & $6(100,0)$ & 0,095 \\
\hline Краснуха & $70(67,3)$ & $53(74,7)$ & $12(54,6)$ & $2(40,0)$ & $3(50,0)$ & 0,118 \\
\hline Гострий гепатит В & $83(79,8)$ & $55(77,5)$ & $18(81,8)$ & $4(80,0)$ & $6(100,0)$ & 0,612 \\
\hline Хронічний гепатит В & $67(64,4)$ & $47(66,2)$ & $14(63,6)$ & $3(60,0)$ & $3(50,0)$ & 0,875 \\
\hline Епідемічний паротит & $74(71,2)$ & $56(78,9)$ & $13(59,1)$ & $2(40,0)$ & $3(50,0)$ & 0,063 \\
\hline Гемофільна інфекція & $78(75,0)$ & $57(80,3)$ & $12(54,6)$ & $3(60,0)$ & $6(100,0)$ & 0,036 \\
\hline Бактеріальний менінгіт & $65(62,5)$ & $49(69,0)$ & $10(45,5)$ & $3(60,0)$ & $3(50,0)$ & 0,219 \\
\hline
\end{tabular}

Примітка: $\mathrm{p}$ - розбіжності між групами за критерієм $\chi^{2}$ Пірсона.

За зваженою квадратичною каппою Коена визначено відмінну силу узгодженості між загальними оцінками та думками ЛЗП / СЛ (к=0,910; 95\% ДІ 0,8530,967); добру - між загальними оцінками та думками експертів (к=0,604; 95\% ДІ 0,422-0,785) і вузьких спеціалістів ( $=0,722 ; 95 \%$ ДІ 0,539-0,905) та посередню в узгодженості організаторів охорони здоров'я та загальної вибірки ключових інформаторів ( $=0,346 ; 95 \%$ ДІ 0,122-0,570).

Помірною $є$ узгодженість висновків експертів 3 іншими групами опитаних: 3 сімейними лікарями ( $=0,458 ; 95 \%$ ДІ 0,210 - 0,705), з вузькими спеціалістами ( $=0,540 ; 95 \%$ ДІ 0,324 - 0,756), організаторами охорони здоров'я $(\kappa=0,497 ; 95 \%$ ДІ $0,224-0,769)$. 
Відсутність достатнього рівня узгодженості між різними групами ключових респондентів та наявність високих рівнів спорідненості між окремими вибірками опитаних (за виключенням фахівців з ООЗ) та загальними оцінками, дозволило нам зробити висновок про доцільність визначення пріоритетних ЗПАЛ саме за загальними оцінками.

3 урахуванням зазначеного підходу, у множині гострих захворювань перші три рангових місця за рівнем значущості для України займають наступні ЗПАЛ: пневмонія, інфекції нирок та інфекції шкіри та підшкірної клітковини; серед хронічних захворювань - діабет, гіпертонічна хвороба/артеріальна гіпертензія, стенокардія, ХОЗЛ та бронхіальна астма, серед вакцино-керованих станів - дифтерія, туберкульоз органів дихання та кір.
На думку ключових інформаторів саме цим ЗПАЛ слід приділити особливу увагу в Україні.

Серед причин, чому обрані ЗПАЛ $є$ найбільш значущими в Україні (рис. 1), пріоритетними визначаються висока частота госпіталізацій при захворюванні - 56,7\% (95\% ДІ 47,2-66,3), значна частка в загальній структурі госпіталізованих - 49,0\% (95\% ДІ 39,4-58,6) та чинники, пов'язані 3 потенційними можливостями надання в первинній та вторинній амбулаторній ланці умов для ефективної роботи: відповідного матеріально-технічного забезпечення ПМСД та амбулаторної спеціалізованої допомоги, відповідної підготовки лікарів спеціалістів амбулаторних закладів (поліклінік, консультативно-діагностичних центрів), організаційних перетворень в системі ПМСД.
Висока частота госпіталізацій при захворюванні

Значна частка в загальній структурі госпіталізованих

Існують потенційні можливості за умови відповідної підготовки лікарів ПМСД

Існують потенційні можливості за умови відповідного матеріально-технічного забезпечення системи ПМСД

Наявні організаційні, кадрові та технологічні можливості в системі ПМСД

Існують потенційні можливості за умови організаційних перетворень в системі ПМСД

Існують потенційні можливості за умови відповідної підготовки лікарів спеціалістів амбулаторних закладів (поліклінік, консультативно-діагностичних центрів)

Існують потенційні можливості за умови відповідного матеріально-технічного забезпечення амбулаторної спеціалізованої допомоги

Існують потенційні можливості за умови організаційних перетворень в системі амбулаторної спеціалізованої допомоги

Наявні організаційні, кадрові та технологічні можливості в системі амбулаторної спеціалізованої допомоги
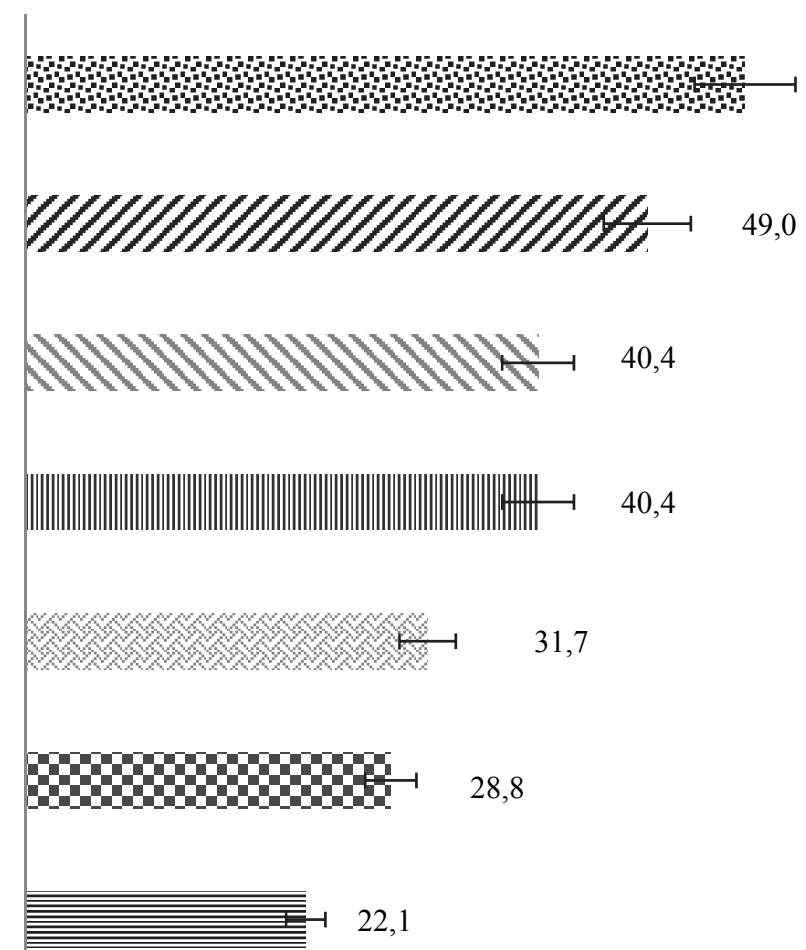

31,7

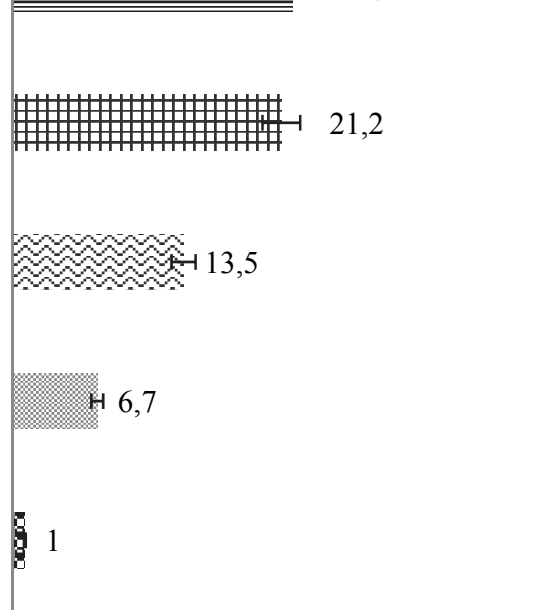

Рис. 1. Причини значущості запропонованих захворювань, що піддаються амбулаторному лікуванню, для дорослого населення України на думку ключових інформаторів (у \% до загального числа опитаних та 95\% ДI) 
Найменший пріоритет серед комплексу чинників, і відповідно несуттєву роль відіграє наявність організаційних, кадрових та технологічних можливостей в системі амбулаторної спеціалізованої допомоги, що свідчить про вкрай низький рівень забезпеченості щодо ефективної діяльності вторинної ланки медичної допомоги.

У загальному рейтингу значущості ЗПАЛ для української охорони здоров'я, без прив'язки до типу захворювань та 3 об'єднанням усіх захворювань, яким можна запобігти за допомогою імунізації в одну групу, окрім туберкульозу органів дихання та грипу (відповідно до статистичного аналізу рівнів госпіталізації ЗПАЛ), перші 10 рангових місць на думку ключових інформаторів, займають такі стани (у порядку убування рангового місця): цукровий діабет, пневмонії, гіпертонічна хвороба, туберкульоз та вакцино-контрольовані захворювання в цілому, стенокардія, ХОЗЛ, бронхіальна астма, грип, проривна або кровоточива виразка шлунку та 12-палої кишки. На останніх рангових місцях щодо важливості національних амбулаторно-чутливих станів на думку опитаних ключових інформаторів, розташувалися у порядку убування до найменш значущого: хронічна виразка шлунку та 12-палої кишки, залізодефіцитна анемія, інфекції нирок, хронічна / застійна серцева недостатність, епілепсія, запальні захворювання малого таза (сальпінгіт, оофорит), інфекції шкіри та підшкірної клітковини.

Об'єднання результатів щодо оцінок значущості ЗПАЛ для дорослого населення України за даними статистичного аналізу та на думку ключових інформаторів проводилося за допомогою двомірного графічного аналізу (рис. 2), згідно якого до найбільш пріоритетних амбулаторно-чутливих станів відносяться захворювання, що отримали першість в обох частинах оцінювання: пневмонії, гіпертонічна хвороба туберкульоз легень, стенокардія тощо.

Отже, у якості маркерів для подальшої поглибленої оцінки госпіталізацій при ЗПАЛ, як індикаторів ефективності надання ПМСД в Україні, для групи гострих захворювань визначено пневмонії; для хронічних цукровий діабет, гіпертонічну хворобу / артеріальну гіпертензію, стенокардію, для захворювань, яким можна запобігти за допомогою імунізації - туберкульоз легень.

Рівень узгодженості оцінок за визначеними маркерними ЗПАЛ $є$ наближеним до відмінного за показником зваженої квадратичної каппи Коена $(\kappa=0,771$; 95\% ДІ 0,554-0,989).

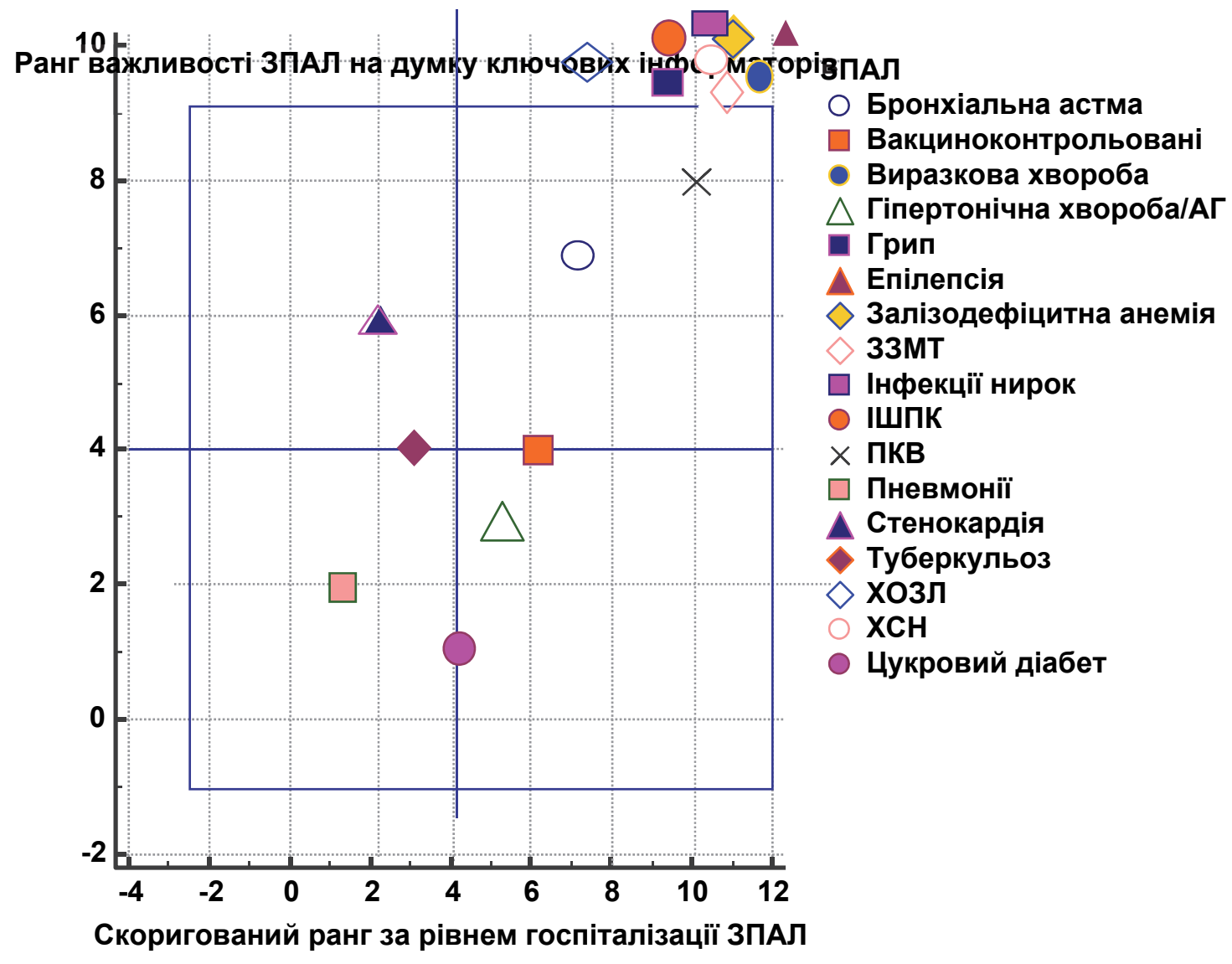

АГ - артеріальна гіпертензія; ІШПК - інфекції шкіри та підшкірної клітковини; ЗПАЛ - захворювання, що піддаються амбулаторному лікуванню; З3МТ - запальні захворювання малого таза (сальпінгіт, оофорит); ПКВ - проривна або кровоточива виразка шлунку та 12-палої кишки; ХОЗЛ - хронічні обструктивні захворювання легень;

ХCH - хронічна / застійна серцева недостатність

Рис. 2. Співвідношення оцінок значущості ЗПАЛ для дорослого населення України за даними статистичного аналізу та на думку ключових інформаторів (ранги від 1 - найбільш важливий стан до 17 - найменш важливий) 
Перспективи подальших досліджень полягають у оцінці обсягів запобіжних госпіталізацій, як за повним переліком ЗПАЛ, так і визначеними пріоритетними патологіями.

\section{Висновки}

Попри більше ніж 15-річну наявність концепції захворювань, що піддаються амбулаторному лікуванню в європейському науковому медичному просторі, в Україні при великій кількості розробок, присвячених організації медичної допомоги на первинній ланці, досліджень ЗПАЛ за існуючими рекомендаціями ВООЗ до теперішнього часу не проводилося.

За результатами дослідження встановлено, що до переліку найактуальніших для України ЗПАЛ, визначеного на підставі аналізу узагальнених статистичних даних, що враховує передусім такі об'єднані характеристики як частоту госпіталізації на 100 тисяч населення та рівень госпіталізації за окремим ЗПАЛ (\% від хворих 3 даною патологією) $є$ пневмонія, стенокардія, туберкульоз органів дихання, цукровий діабет, гіпертонічна хвороба, вакцино-контрольовані захворювання, бронхіальна астма, проривна виразка шлунку та 12-палої кишки і шлунково-кишкова кровотеча, інфекції шкіри та підшкірної клітковини, ХОЗЛ.

За результатами опитування 104-х ключових інформаторів, включно 3 відокремленою групою експертів, визначено, що до ЗПАЛ в Україні, які потребують особливої уваги відносяться пневмонія, проривна або кровоточива виразка шлунку та 12-палої кишки й інфекції нирок (для гострих захворювань); діабет, гіпертонічна хвороба/артеріальна гіпертензія, стенокардія, ХОЗЛ та бронхіальна астма (для хронічних захворювань); дифтерія, туберкульоз органів дихання та кір (для захворювань, яким можна запобігти за допомогою імунізаціі).

У якості репрезентативних маркерів для подальшої детальної оцінки частки госпіталізацій при ЗПАЛ, як індикаторів ефективності надання ПМСД, визначено по 1-3 пріоритетних захворювань з кожної групи, зокрема це пневмонія, цукровий діабет, артеріальна гіпертензія, стенокардія та туберкульоз легень.

Серед причин актуальності для Україні саме даних визначених ЗПАЛ, виступають їх висока частота госпіталізацій, значна частка в загальній структурі госпіталізованих і фактори, що обумовлюють високий потенціал (матеріально-технічний, кадровий та організаційний) надання амбулаторних послуг первинного та вторинного рівнів.

Концепція ЗПАЛ у сучасних умовах не втрачає своєї актуальності через можливість при наявності адекватної політики в охороні здоров'я призводити до підвищення ефективності ПМСД, зміцнення галузі в цілому та оптимізації витрат обмежених ресурсів. Актуальність проблеми посилюється в умовах необхідності збалансувати потреби та заходи оперативного реагування на загрозу COVID-19 із забезпеченням основних послуг охорони здоров'я при зменшенні ризику колапсу системи.

\section{References}

1. Grabovec'kyj B. Je. Metody ekspertnyh ocinok: teorija, metodologija, naprjamky vykorystannja : monografija. Vinnycja : VNTU, 2010. 171 s. [in Ukrainian].

2. Lekhan V.N., Kriachkova L.V., Zaiarskyi M.I., Borvinko E.V. Ukrainian version of appropriateness evaluation protocol and criteria of inpatient care duration. World of medicine and biology. 2019; 3(69): 94-100. [in Ukrainian]. DOI 10.26724/2079-8334-2019-3-69-94-100.

3. Altman D. G. Practical statistics for medical research. London : Chapman and Hall, 1991. 611 p.

4. Ambulatory care sensitive conditions in Germany. World Health Organization. WHO Regional Offce for Europe: Copenhagen, 2015. 43 p.

5. Ambulatory care sensitive conditions in Kazakhstan. World Health Organization. WHO Regional Offce for Europe: Copenhagen, 2015. $46 \mathrm{p}$.

6. Ambulatory care sensitive conditions in Latvia. World Health Organization. WHO Regional Offce for Europe: Copenhagen, 2015. 34 p.

7. Ambulatory care sensitive conditions in Portugal. World Health Organization. WHO Regional Offce for Europe: Copenhagen, 2016. 38 p.

8. Ambulatory care sensitive conditions in the Republic of Moldova. World Health Organization. WHO Regional Offce for Europe: Copenhagen, 2015. 30 p.

9. Assessing health services delivery performance with hospitalizations for ambulatory care sensitive conditions. World Health Organization. WHO Regional Offee for Europe: Copenhagen, 2016. 43 p.

10. Bardsley M., Blunt I., Davies S., Dixon J. Is secondary preventive care improving? Observational study of 10-year trends in emergency admissions for conditions amenable to ambulatory care. BMJ Open. 2013. №3:e002007. doi: 10.1136/bmjopen-2012-002007.

11. Billings J., Teicholz N. Uninsured patients in District of Columbia hospitals. Health Aff Proj Hope. 1990. №9(4). P. 158 - 165. https://doi.org/10.1377/hlthaff.9.4.158.

12. Caminal J., Starfeld B., Sánchez E., Casanova.C, Morales M. The role of primary care in preventing ambulatory care sensitive conditions. Eur J Public Health. 2004. №14(3). P. 246 - 251. https://doi.org/10.1093/eurpub/14.3.246. 
13. Coronavirus disease (COVID-19) technical guidance: Maintaining Essential Health Services and Systems. COVID19: Operational guidance for maintaining essential health services during an outbreak. WHO/2019-nCoV/immunization services/2020.1. World Health Organization, 2020. 3 p. https://apps.who.int/iris/bitstream/handle/10665/331590/WHO-2019nCoV-immunization_services-2020.1-eng.pdf.

14. Fleetcroft R., Hardcastle A., Steel N., Price G.M., Purdy S., Lipp A., Myint P.K., Howe A. Does practice analysis agree with the ambulatory care sensitive conditions' list of avoidable unplanned admissions?: a cross-sectional study in the East of England. BMJ Open. 2018 Apr 28. № 8(4): e020756. doi: 10.1136/bmjopen-2017-020756.

15. Hodgson K, Deeny SR, Steventon A Ambulatory care-sensitive conditions: their potential uses and limitations. BMJ Quality \& Safety. 2019. №28. P. 429-433. http://dx.doi.org/10.1136/bmjqs-2018-008820.

16. Purdy S., Griffin T., Salisbury C., Sharp D. Ambulatory care sensitive conditions: terminology and disease coding need to be more specific to aid policy makers and clinicians. Public Health 2009. №123. P. 169-173. DOI: 10.1016/j.puhe.2008.11.001.

17. Vuik S.I., Fontana G., Mayer E, Darzi A. Do hospitalisations for ambulatory care sensitive conditions reflect low access to primary care? An observational cohort study of primary care usage prior to hospitalisation. BMJ Open. 2017 Aug 21. №7(8): e015704. doi: 10.1136/bmjopen-2016-015704.

18. Zhao F., Doroshenko O., Lekhan V.N., Kriachkova L.V., Goroshko A. Assessment of appropriateness of hospitalisations in Ukraine: analytical framework, method and findings. BMJ Open. 2019. №9: e030081. doi: 10.1136/bmjopen2019-030081.

Дата надходження рукопису до редакції: 02.03.2020 p.

\begin{abstract}
Мета дослідження - виявлення найбільш актуальних на теперішній час захворювань, що піддаються амбулаторному лікуванню (ЗПАЛ) для дорослого населення (старше 18-ти років) України (вичерпний перелік з 810 захворювань) та визначення найбільш пріоритетних - маркерних ЗПАЛ, як індикаторів ефективності надання первинної допомоги (2-4 захворювання).

Матеріали і методи. Згідно методологічних рекомендацій ВООЗ щодо оцінки ЗПАЛ в Європейському регіоні, проведене багатоступеневе адаптоване до національних реалій дослідження за участю 104 ключових інформаторів представників зацікавлених сторін: сімейних лікарів, вузьких спеціалістів, організаторів охорони здоров'я та виділеної групи експертів. Опитування проводилося за стандартизованою анкетою для самоаналізу ЗПАЛ після великої підготовчої роботи щодо визначення переліку амбулаторно-чутливих станів та аналізу наявної статистичної інформації щодо їх рівнів госпіталізації.
\end{abstract}

Результати. До найбільш значущих для України ЗПАЛ які потребують особливої уваги за інтегрованою оцінкою статистичних даних та думок опитаних респондентів відносяться пневмонія, проривна або кровоточива виразка шлунку та 12-палої кишки й інфекції нирок (для гострих захворювань); діабет, гіпертонічна хвороба/артеріальна гіпертензія, стенокардія, ХОЗЛ та бронхіальна астма (для хронічних захворювань); дифтерія, туберкульоз органів дихання та кір (для захворювань, яким можна запобігти за допомогою імунізації).

Висновки. Концепція ЗПАЛ у сучасних умовах не втрачає своєї актуальності через можливість зміцнення систем охорони здоров'я за рахунок первинної ланки та збалансування потреб і заходів оперативного реагування на загрозу COVID-19. Визначено, що у якості репрезентативних маркерів ефективності надання ПМСД в Україні виступають такі ЗПАЛ, пневмонія, цукровий діабет, артеріальна гіпертензія, стенокардія та туберкульоз легень.

Ключові слова: захворювання, що піддаються амбулаторному лікуванню, рівень госпіталізації, опитування ключових інформаторів.

Цель исследования - выявление наиболее актуальных в настоящее время заболеваний, поддающихся амбулаторному лечению (ЗПАЛ) для взрослого населения (старше 18 лет) Украины (исчерпывающий перечень из 810 заболеваний) и определение наиболее приоритетных - маркерных ЗПАЛ, в качестве индикаторов эффективности предоставления первичной помощи (2-4 заболевания).

Материалы и методы. В соответствии с методологическими рекомендациями ВОЗ по оценке ЗПАЛ в Европейском регионе, проведенное многоступенчатое адаптированное к национальным реалиям исследование с участием 104 ключевых информаторов - представителей заинтересованных сторон: семейных врачей, узких специалистов, организаторов здравоохранения и выделенной группы экспертов. Опрос проводился по стандартизированной анкете для самоанализа ЗПАЛ после большой подготовительной работы по определению перечня амбулаторно-чувствительных состояний и анализа имеющейся статистической информации по уровню их госпитализации.

Результаты. К наиболее значимым для Украины ЗПАЛ, требующим особого внимания, по данным интегрированной оценки статистических данных и мнений опрошенных респондентов, относятся: пневмония, прободная или кровоточащая язва желудка и 12-перстной кишки, инфекции почек (для острых заболеваний); диабет, гипертоническая болезнь / артериальная гипертензия, стенокардия, хроническая обструктивная болезнь легких и 
бронхиальная астма (для хронических заболеваний); дифтерия, туберкулез органов дыхания и корь (для заболеваний, которые можно предотвратить с помощью иммунизации).

Выводы. Концепция ЗПАЛ в современных условиях не теряет своей актуальности из-за возможности укрепления систем здравоохранения за счет первичного звена и сбалансирования потребностей и мер оперативного реагирования в связи с угрозой COVID-19. Определено, что в качестве репрезентативных маркеров эффективности предоставления ПМСП в Украине выступают такие ЗПАЛ как пневмония, диабет, артериальная гипертензия, стенокардия и туберкулез легких.

Ключевые слова: заболевания, поддающиеся амбулаторному лечению, уровень госпитализации, опрос ключевых информаторов.

The purpose of the study was to identify the most relevant ambulatory care sensitive conditions (ACSCs) for the adult population (over 18 years old) in Ukraine (an exhaustive list of 8 to 10 diseases) and to identify the highest priority marker ACSCs as indicators of the effectiveness of primary care (2 to 4 diseases).

Materials and methods. In accordance with the WHO methodological recommendations for assessing ACSC in the European Region, a multistage study adapted to national realities involving 104 key informants - representatives of interested parties: general practitioners, specialists, health managers and a dedicated expert group.. The survey was conducted on a standardized questionnaire for self-analysis of ACSC after a lot of preparatory work to determine the list of ambulatory-sensitive conditions and analyze available statistical information on the hospital discharges.

Results. According to the integrated assessment of statistical data and the opinions of the respondents, the most significant ACSC $\mathrm{s}$ in Ukraine that require special attention include: pneumonia, perforated/bleeding ulcer, pyelonephritis (for acute diseases); diabetes, hypertension, angina Pectoris, chronic obstructive pulmonary disease, asthma (for chronic diseases); diphtheria, tuberculosis, measles (for Immunization-preventable conditions)

Conclusions. The conception of ACSC in modern conditions does not lose its relevance due to the possibility of strengthening the health systems at the expense of primary care and balancing the needs and measures of prompt response in connection with the threat COVID-19. It has been determined that such ACSCs as pneumonia, diabetes, hypertension, angina pectoris and tuberculosis are the representative markers of the effectiveness of providing PHC in Ukraine.

Key words: ambulatory care sensitive conditions, hospital discharges, survey of key informants.

Конфлікт інтересів: відсутній.

Conflicts of interest: authors have no conflicts of interest to declare.

\section{Відомості про авторів}

Лехан Валерія Микитівна (автор для листування) - д.мед.н, професор; Державний заклад «Дніпропетровська медична академія Міністерства охорони здоров'я України», завідувач кафедри соціальної медицини, громадського здоров’я та управління охороною здоров'я; 49044, пр. Д. Яворницького, 24, ДЗ «ДМА МОЗ України», навчальний корпус № 2, м. Дніпро.

+380 (56) 713-51-84, +380 (67) 713-71-18; +380 (99) 986-04-38, v.n.lexan@gmail.com, social.medicine.pg@dma.dp.ua.

Крячкова Лілія Вікторівна - д.мед.н., доцент; Д3 «Дніпропетровська медична академія МОЗ України»; професор кафедри соціальної медицини, громадського здоров’я та управління охороною здоров'я.

Сердюк Валерій Миколайович - д.мед.н, професор; директор Департаменту охорони здоров’я Дніпропетровської обласної державної адміністрації; 49004, пр. Олександра Поля, 2, м. Дніпро.

+380 (56) 742-87-62, guoz@adm.dp.gov.ua.

Пучкова Надія Володимирівна - експерт за напрямом «загальна практика - сімейна медицина» Департаменту охорони здоров’я Дніпропетровської обласної державної адміністрації.

Борвінко Ельвіра Вікторівна - к.мед.н., доцент; Д3 «Дніпропетровська медична академія МОЗ України»; доцент кафедри соціальної медицини, громадського здоров’я та управління охороною здоров’я.

Гриценко Людмила Олександрівна - ДЗ «Дніпропетровська медична академія МОЗ України»; викладач кафедри соціальної медицини, громадського здоров'я та управління охороною здоров'я.

Заярський Микола Іванович - к.мед.н., доцент; Д3 «Дніпропетровська медична академія МОЗ України»; доцент кафедри соціальної медицини, громадського здоров'я та управління охороною здоров'я. 